\title{
A scientific note on the first record of nesting sites of Peponapis crassidentata (Hymenoptera: Apidae)
}

\author{
Oliverio Delgado-Carrillo ${ }^{1,2}$, Martha Lopezaraiza-Mikel ${ }^{2,3}$, Lorena Ashworth ${ }^{2,4}$, Ramiro Aguilar ${ }^{2,4}$, \\ Jorge A. LoBO ${ }^{2,5}$, Mauricio QuesAdA ${ }^{1,2}$ \\ ${ }^{1}$ Instituto de Investigaciones en Ecosistemas y Sustentabilidad, Universidad Nacional Autónoma de México, Apartado Postal 27-3, \\ 58089, Morelia, Michoacán, Mexico \\ ${ }^{2}$ Laboratorio Nacional de Análisis y Síntesis Ecológica (LANASE), Escuela Nacional de Estudios Superiores Unidad Morelia, \\ Universidad Nacional Autónoma de México, 58190, Morelia, Michoacán, Mexico \\ ${ }^{3}$ Facultad de Desarrollo Sustentable, Universidad Autónoma de Guerrero, 40900, Tecpan de Galeana, Guerrero, Mexico \\ ${ }^{4}$ Instituto Multidisciplinario de Biología Vegetal, Universidad Nacional de Córdoba - CONICET, 5000, Córdoba, Argentina \\ ${ }^{5}$ Escuela de Biología, Universidad de Costa Rica, San José 2060, Costa Rica
}

Received 23 September 2016 - Revised 6 February 2017 - Accepted 15 March 2017

solitary bees / nesting behavior / Peponapis nests

Peponapis is a genus of solitary bees that breeds once a year, nests in the ground, and is distributed exclusively in the Americas. Mexico is considered its center of origin, holding all 15 currently known species of Peponapis (Hurd et al. 1971; Ayala and Griswold 2012). Peponapis spp. are closely associated with the plant genus Cucurbita (Hurd et al. 1971; Hurd et al. 1974), whose center of origin is also Mexico (LiraSaade 1995). Peponapis pruinosa (Say, 1837) in North America and Peponapis limitaris (Cockerell, 1906) in Mexico are the most effective pollinators of Cucurbita spp. (e.g., Canto-Aguilar and Parra-Tabla 2000; Minter and Bessin 2014). The pollen of Cucurbita also seems to be the main food source of some Peponapis sp. larvae (Hurd et al. 1974). Little is known about the natural history of most Peponapis species, and only nest descriptions of P. pruinosa (Mathewson 1968; Hurd et al. 1974), P. fervens (Smith, 1879) (Michener and Lange 1958; Krug et al. 2010), and P. utahensis (Cockerell, 1905) (Rozen and Ayala 1987) are known under natural conditions. Most studies of Peponapis are taxonomic descriptions and observations of Cucurbita flower visitation by these bees (Hurd and Linsley 1966;

Corresponding author: M. Quesada, mquesada@cieco.unam.mx

Manuscript editor: Stan Schneider
Wille 1985; Ayala and Griswold 2012). Here, we describe the nesting sites and the structure of nests of Peponapis crassidentata (Cockerell, 1949).

P. crassidentata (Figure 1a) is distributed from southern Texas (USA) to Costa Rica (Wille 1985; Giannini et al. 2011), and it has been observed foraging on Cucurbita flowers (Wille 1985). No other information has been reported for this species. We searched for nesting sites of $P$. crassidentata near Cucurbita moschata Lam. crops in the coastal region of Jalisco state, Mexico. In November and December 2014, we found two nesting sites (sites 1 and 2), and in January 2016, a third nesting site (site 3, Table I). These sites were found along temporary streams with riparian vegetation surrounded by tropical dry forest. We registered 188 nests (Table I). Nesting activity occurred within the flowering season of nearby cultivated C. moschata (Jul-Dec 2014 and Nov 2015-Mar 2016) and wild Cucurbita argyrosperma Huber (Jun-Dec 2014 and 2016). From February onwards, we did not observe bees provisioning nests or visiting flowers at any site. In January 2016, there was no activity of adult bees at the nests found in 2014.

Nest descriptions We found nests in bare vertical walls of sandy soil and mud in river banks shaded by vegetation, making nest entrances inconspicuous. All nests formed a tunnel, and their entrances 

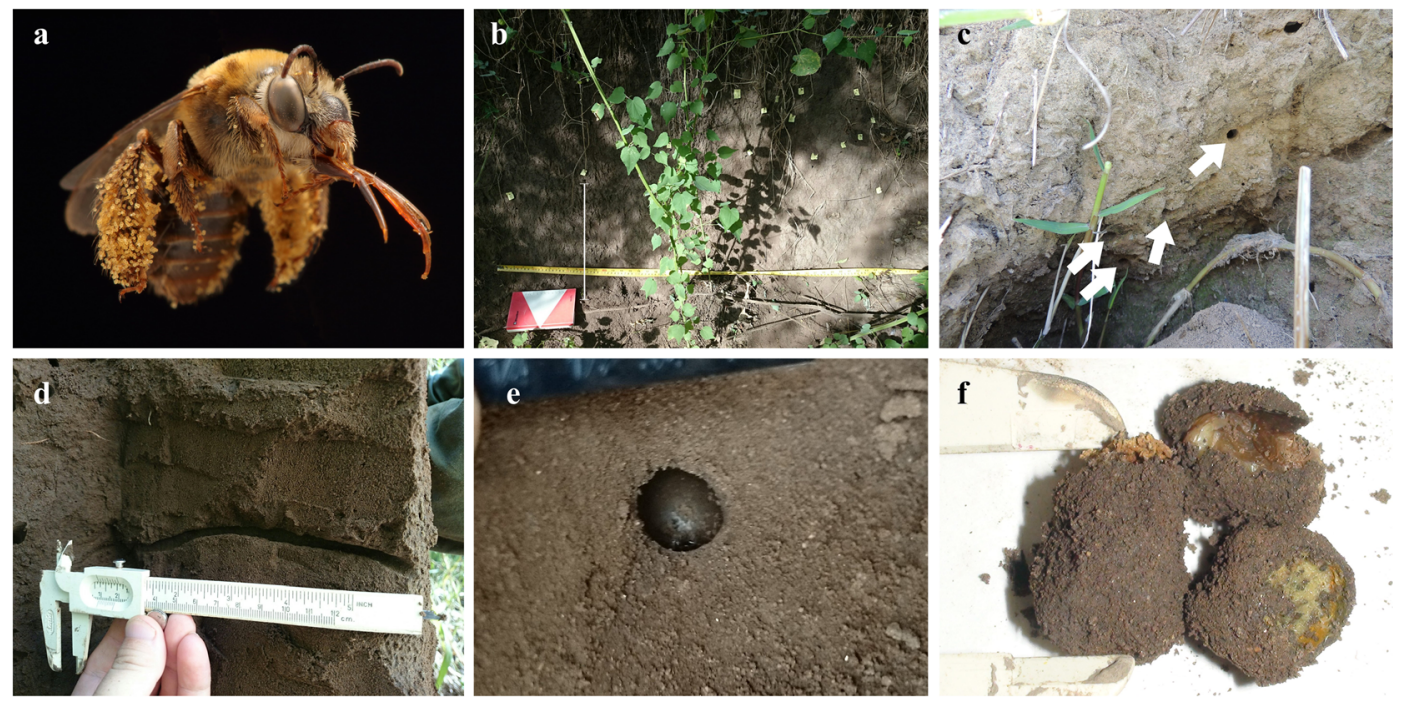

Figure 1. a Peponapis crassidentata female. b Nests on a river wall. Each nest is marked with a yellow piece of paper. $\mathbf{c}$ Nests on the roof of a cavity at a river wall; white arrows show the active nests. $\mathbf{d}$ Cross section of active nests. e Chamber with a waterproof and shiny lining. f Cells containing larvae of $P$. crassidentata .

were located horizontally on the walls (Figure 1b) and vertically on the roof of a cavity (Figure 1c). Beneath the entrance of active nests, we found loose soil and Cucurbita pollen. We excavated two nests in 2014, and no antechamber was observed. Tunnels wound and descended horizontally (Figure 1d); the tunnel substrate was of homogeneous, sandy, moist soil, and in the brood cells, the floor was also moist but more clayey. The tunnel walls were smooth. The brood cells were at $35-95 \mathrm{~cm}$ from the entrance. The cells were located vertically adjacent to the tunnel floor but separated by soil from the main tunnel. The first nest was $120 \mathrm{~cm}$ long and contained 14 brood cells. The second nest was $95 \mathrm{~cm}$ long and contained only one cell. The interior walls of the brood cells were smooth and dark, with a waterproof and shiny lining (Figure 1e), similar to the cell walls of $P$. pruinosa (Mathewson 1968), P. fervens (Michener and Lange 1958), and P. utahensis (Rozen and Ayala 1987). The brood cells were ovoid chambers, each containing one larva with its respective pollen supply (Figure 1f) or one pupa. Due to a large number of nests, it was not possible to determine if all 14

Table I. Description of the three nesting sites of Peponapis crassidentata. Values for nest traits are mean $\pm \mathrm{sd}$

\begin{tabular}{|c|c|c|c|c|c|c|}
\hline Site & $\begin{array}{l}\text { Geographical } \\
\text { coordinates }\end{array}$ & $\begin{array}{l}\text { Number } \\
\text { of nests }\end{array}$ & $\begin{array}{l}\text { Wall } \\
\text { length } \times \\
\text { height } \\
(\mathrm{m})\end{array}$ & $\begin{array}{l}\text { Distance }(\mathrm{cm}) \text { from the nest entrance } \\
\text { to the horizontal plane of the floor } \\
\text { (white bar in } 1 \mathrm{~b} \text { ) }\end{array}$ & $\begin{array}{l}\text { Nest } \\
\text { diameter } \\
(\mathrm{cm})\end{array}$ & $\begin{array}{l}\text { Distance from } \\
\text { the nearest } \\
\text { crop }(\mathrm{m})\end{array}$ \\
\hline 1 & $\begin{array}{l}19^{\circ} 36^{\prime} 11^{\prime \prime} \mathrm{N} \\
105^{\circ} 6^{\prime} 15.1^{\prime \prime} \\
\mathrm{W}\end{array}$ & 164 & $4.2 \times 1.8$ & $112.8 \pm 38.2$ & $0.67 \pm 0.05$ & 100 \\
\hline 2 & $\begin{array}{l}19^{\circ} 35^{\prime} 15^{\prime \prime} \mathrm{N} \\
105^{\circ} 6^{\prime} 7.8^{\prime \prime} \\
\mathrm{W}\end{array}$ & 16 & $5 \times 0.9$ & $46.1 \pm 11.5$ & $0.68 \pm 0.04$ & 20 \\
\hline 3 & $\begin{array}{l}19^{\circ} 23^{\prime} 19.2^{\prime \prime} \\
\mathrm{N} \\
104^{\circ} 58^{\prime} \\
15.4^{\prime \prime} \mathrm{W}\end{array}$ & 8 & $9.5 \times 1.9$ & $82.5 \pm 0.75$ & $0.65 \pm 0.04$ & 55 \\
\hline
\end{tabular}


cells belonged to the same nest that was originally dug up. The cells of the first excavated nest contained an exarate pupa, six pupae, and seven larvae, the cell of the second nest contained one larva. We sampled pollen from excavated cells and confirmed under a microscope that all samples contained only Cucurbita pollen. This coincides with the observation, in the same period, of individuals of $P$. crassidentata foraging on $C$. mos chata and $C$. argyrosperma in the area.

Discussion Previous reports on the nesting biology of Peponapis spp. contrast with some patterns observed here for $P$. crassidentata. While $P$. pruinosa, $P$. utahensis, and $P$. fervens nest on flat ground with vertical entrances located in proximity to their pollen sources (Mathewson 1968; Hurd et al. 1974; Rozen and Ayala 1987; Krug et al. 2010), P. crassidentata nests on vertical river banks, mainly with horizontal nest entrances. Another notable difference is that $P$. pruinosa and $P$. fervens nest in exposed and semi-exposed sites (Michener and Lange 1958; Mathewson 1968; Krug et al. 2010), whereas $P$. utahensis and $P$. crassidentata prefer shaded sites near riparian habitats. Such feature is possibly associated with temperature regulation of nests during the day. A shared characteristic by all Peponapis spp. studied is their gregarious nesting habit during the flowering period of nearby Cucurbita flowers.

By nesting on the walls of river banks, away from main crops, $P$. crassidentata may be less susceptible to destruction by plowing. In contrast, because $P$. pruinosa nests on flat ground, agricultural practices can affect population density by delaying the emergence of offspring (Ullmann et al. 2016; Shuler et al. 2005). Other disturbances such as fire, agrochemicals, and sand and gravel extraction are important threats to all Peponapis species, including $P$. crassidentata. Such knowledge must be conveyed to farmers, who are often unaware of the identity and biology of Peponapis species that are the most efficient pollinators of Cucurbita cultivars. This study will allow identification, protection, and perhaps creation of potential nesting sites of $P$. crassidentata.

Our study suggests that riparian habitats are essential for $P$. crassidentata nesting. Riparian habitats cover only $4 \%$ of the study area but provide resources for the maintenance of many other animal species, particularly during the dry season (Sanchez-Azofeifa et al. 2009). These areas are key for maintaining the biodiversity and ecosystem services of tropical dry forests and deserve special attention to ensure the integrity of pollination services, such as the important evolutionary interaction of Peponapis spp. with squashes in Mesoamerica (Hurd et al. 1971).

\section{ACKNOWLEDGEMENTS}

The authors would like to thank P. J. Ramello and L. Alvarez for the help in identifying $P$. crassidentata, and E. Paramo, E. Perez, G. Sanchez-Montoya, U. OlivaresPinto, V. Patiño and C. Orduña for the field assistance. JC Garcia took picture 1a. ODC is a $\mathrm{PhD}$ student from Programa de Doctorado en Ciencias Biomédicas, Universidad Nacional Autónoma de México (UNAM), fellowship 50222 from CONACyT. This work was supported by grants from DGAPA-UNAM (PAPIIT \# 212714 to MQ) and CONACyT (CB-2009-131008 to MQ, CB-2014-01-241696 to ML, Proyecto Laboratorio Nacional de Análisis y Síntesis Ecológica 2015250996, 2016-271449, and 2017-280505 to MQ).

Contributions All authors have contributed equally to the work.

Note scientifique sur la première observation de sites de nidification de Peponapis crassidentata (Hymenoptera: Apidae)

Eine wissenschaftliche Anmerkung über die erste Beschreibung des Nistplatzes von Peponapis crassidentata (Hymenoptera: Apidae)

\section{REFERENCES}

Ayala, R., Griswold, T. (2012) Two new species of the bee genus Peponapis, with a key to the North and Central American species (Hymenoptera: Apidae: Eucerini). Rev. Mex. Biodivers. 83, 396-406.

Canto-Aguilar, M. A., Parra-Tabla, V. (2000) Importance of conserving alternative pollinators: assessing the pollination efficiency of the squash bee, Peponapis limitaris in Cucurbita moschata (Cucurbitaceae). J. Insect Conserv. 4, 201-208.

Giannini, T. C., Lira-Saade, R., Ayala, R., Saraiva, A. M., Alvesdos-Santos, I. (2011) Ecological niche similarities of Peponapis bees and non-domesticated Cucurbita species. Ecol. Model. 222, 2011-2018.

Hurd, P. D., Linsley, E. G. (1966) The Mexican Squash and Gourd Bees of the Genus Peponapis (Hymenoptera: Apoidea). Ann. Entomol. Soc. Am. 59, 835-851.

Hurd, P. D., Linsley, E.G., Whitaker, T. W. (1971) Squash and gourd bees (Peponapis, Xenoglossa) and the origin of the cultivated Cucurbita. Evolution 25, 218-234.

Hurd, P. D., Linsley, E.G., Michelbacher, A. E. (1974). Ecology of the squash and gourd bee, Peponapis pruinosa, on cultivated 
cucurbits in California (Hymenoptera: Apoidea). Smithsonian Institution Press.

Krug, C., Alves-dos-Santos, I., Cane, J. (2010) Visiting bees of Cucurbita flowers (Cucurbitaceae) with emphasis on the presence of Peponapis fervens Smith (Eucerini-Apidae) Santa Catarina, Southern Brazil. Oecologia Aust. 14,128-139.

Lira-Saade, R. 1995. Estudios taxonómicos y ecogeográficos de las Cucurbitaceae latinoamericanas de importancia económica: Systematic and Ecogeographic Studies on Crop Genepools. 9. International Plant Genetic Resources Institute/Instituto de Biología, Universidad Nacional Autónoma de México. Rome, Italy.

Mathewson, J. A. (1968) Nest construction and life history of the eastern cucurbit bee, Peponapis pruinosa (Hymenoptera: Apoidea). J. Kansas Entomol. Soc. 41 (2), 255-261.

Michener, C. D., Lange, R. B. (1958) Observations on the ethology of neotropical anthophorine bees (Hymenoptera: Apoidea). Univ. Kansas Sci. Bull. 39, 69-96.

Minter, L. M., Bessin, R. T. (2014) Evaluation of native bees as pollinators of cucurbit crops under floating row covers. Environ. Entomol. 43,1354-1363.
Rozen, J. G., Ayala, R. (1987) Nesting biology of the squash bee Peponapis utahensis (Hymenoptera; Anthophoridae; Eucerini). J. New York Entomol. S. 95 (1), 28-33.

Sánchez-Azofeifa, G. A., Quesada, M., Cuevas-Reyes, P., Castillo, A., Sánchez-Montoya, G. (2009) Land cover and conservation in the area of influence of the Chamela-Cuixmala Biosphere Reserve, Mexico. Forest Ecol. Manag. 258, 907-912.

Shuler, R. E., Roulston, T. H., Farris, G. E. (2005) Farming practices influence wild pollinator populations on squash and pumpkin. J. Econ. Entomol. 98, 790-795.

Ullmann, K. S., Meisner, M. H., Williams, N. M. (2016) Impact of tillage on the crop pollinating, ground-nesting bee, Peponapis pruinosa in California. Agric. Ecosyst. Environ. 232, 240246.

Wille, A. (1985) Las abejas Peponapis y Xenoglossa en Costa Rica y su importancia en la polinización de las Cucurbita domésticas. J. Trop. Biol. Conserv. 33, 17-24. 